\title{
New Record of Woldmaria filicina (Cyphellaceae, Basidiomycota) in Russia
}

\section{Vlasenko VA and Vlasenko AV}

Central Siberian Botanical Garden, Siberian Branch of the Russian Academy of Sciences, Zolotodolinskaya, 101, Novosibirsk630090, RussiaEmail: vlasenkomyces@mail.ru, anastasiamix81@mail.ru

Vlasenko VA, Vlasenko AV 2013 - New Record of Woldmaria filicina (Cyphellaceae, Basidiomycota) in Russia. Mycosphere 4(4), 848-854, Doi 10.5943/mycosphere/4/4/18

\begin{abstract}
This paper provides information on the new record of Woldmaria filicina in Russia. This rare and interesting member of the cyphellaceous fungi was found in the Novosibirsk Region of Western Siberia in the forest-steppe zone, on dead stems of the previous year of the fern Matteuccia struthiopteris. A description of the species is given along with images of fruiting bodies of the fungus and its microstructures, information on the ecology and general distribution and data on the literature and internet sources.
\end{abstract}

Key words - cyphellaceous fungi - forest-steppe - new data - microhabitats - Woldmaria filicina

\section{Introduction}

This paper is devoted to the description of an interesting member of the cyphellaceous fungi - Woldmaria filicina - found for the first time in the vast area of Siberia. This species was previously known from Europe, including the European part of Russia and the Urals but was found the first time in the forest-steppe zone of Western Siberia.

Despite the large scale of the territory and well-studied biodiversity of aphyllophoroid fungi (808 species are known from Western Siberia) this species has not previously been recorded here, and information is provided on the specific substrate and the habitat of the fungus at this new locality.

Cyphellaceous (cyphelloid) fungi (cyphelloid - similar genus Cyphella) represent specific ecomorphs of fungi that can be found among taxonomically diverse taxa belonging to the families Cyphellaceae (Cyphella), Niaceae (Cyphellopsis, Lachnella, Merismodes), Schizophyllaceae (Schizophyllum), Porotheleaceae (Porotheleum), Fistulinaceae (Fistulina) and some other basidiomycete taxa of the order Agaricales.

These fungi have a small fruiting bodies, and the morphological diversity is, in general, represented by cylindrical and cup-shaped structures, attached to the substrate by a narrowed base or short stem, positively or negatively gravitropic, occurring as single fruiting bodies or in groups on a common prostrate mycelial subiculum, including the formation of tubular fruiting bodies (Porotheleum fimbriatum) or on a massive, laterally attached general basis (Fistulina hepatica). The hymenium in these fungi is located on the inner surface of the fruiting bodies, and the hymenophore is smooth. The outer surface is smooth or the fruiting bodies are pubescent. 
The monotypic genus Woldmaria was described by W.B. Cook (1961), with the type genus Woldmaria crocea (P. Karst.) W.B. Cooke. The genus is named after the Swedish mycologist S. Woldmar, who gave a detailed description of the type species (Woldmar 1954). Previously, this species was known as Solenia crocea, described P. Karsten in 1884 on the basis of the type material from Finland. In 1996, H. Knudsen, in a joint paper with L. Hansen (Hansen \& Knudsen 1996) on the taxonomy of fungi in "Nordic Macromycetes" established the new name Woldmaria filicina (Peck) Knudsen for the fungus Solenia filicina, described earlier Peck in 1876. This species, the type of which is known from the United States, was identical to Solenia crocea P. Karsten.

The distribution and ecology of cyphellaceous fungi in Russia and Western Siberia is poorly studied. In the literature of Western Siberia, data exists for 6 species in 5 genera. These genera are Henningsomyces, Rectipilus, Cyphellopsis (Zhukov 1980, Mukhin \& Knudsen 1998, Kotkova 2006), including a rare monotypic genus Porotheleum (Zhukov 1980, Bondartseva \& Parmasto 1986) and the frequently occurring Schizophyllum.

\section{Materials \& Methods}

We used the traditional methods to collect the fruiting bodies in field expeditions (Gilbertson \& Ryvarden 1986). Fruiting bodies of cyphellaceous fungi collected from a part of the substrate were glued to the bottom of a matchbox, transported to the laboratory, where they were studied. For photographing fruiting bodies and habitats of fungi we used a Panasonic-Lumix DFCXZ7 camera. To identify the fungi, we used stereomicroscope Carl Zeiss Stemi DV4 and light microscope Carl Zeiss Axiolab RE. A detailed study of the anatomical and morphological features was performed on a light microscope Carl Zeiss Axioskop-40 and stereo microscope Carl Zeiss Stereo Discovery V 12. For coloring preparations from dried herbarium material was used Melzer's reagent. Herbarium specimens are CSBG SB RAS (NS) Novosibirsk. Sample number assigned by the authors of this publication. Nomenclature is given in accordance with Mycobank (2013).

\section{Results}

Woldmaria filicina (Peck) Knudsen in Knudsen et Hansen, 1996, Nordic J. Bot. 16(2): 219.

- Solenia filicina Peck, 1876, Ann. Rep. N.Y. St. Mus. nat. Hist. 28: 52.

Fig 1-4

- Woldmaria crocea (P. Karst.) W.B. Cooke, 1961, Sydowia Beih. 4: 29.

- Solenia crocea P. Karst., 1884, Hedwigia 23: 88.

-Cyphella struthiopteridis Pilát, 1926, Hedwigia 66: 261.

Description - Basidiocarps small, 1.5-4 mm long, 0.5-1 $\mathrm{mm}$ wide, in separate tubes, crowded together on a common filamentous basis - subicle, or separately attached to the substrate, golden-brown, covered with outside appressed hairs. Subicle one color with fruit bodies, lighter on the edge. Hymenium smooth on the inside of fruiting bodies. Hyphae brown, thin or slightly thick walled 2.5-5 $\mu \mathrm{m}$ width. Subhymenial hyphae hyaline, thin walled. Clamps present. Spores fusiform, smooth, hyaline, 10-15 x 3-4.5 $\mu \mathrm{m}$. Basidia 4-spored, 25-30 x 6-8 $\mu \mathrm{m}$.

Known distribution - Europe: Denmark, Norway, Sweden, Finland, Estonia, Austria, Belgium, United Kingdom, Germany, Poland, Ukraine, Russia. North America: USA (Arizona Lake Pleasant, New York); Canada (Manitoba, Ontario, Québec, Nova Scotia).

Material examined - Russia, Novosibirsk Region, in the vicinity of Novosibirsk, the right bank of the Ob River, ravine network valley Zyrianka river, on dead stems of the previous year of the fern Matteuccia struthiopteris in vegetation communities $M$. stratiopteris + Aconitum septentrionale + Equisetum sylvaticum, at the bottoms of the ravine, 15 September 2010, V.A. Vlasenko, A.V. Vlasenko, herbarium NS, number collector 1509101.

Notes - Grows with July to October. 

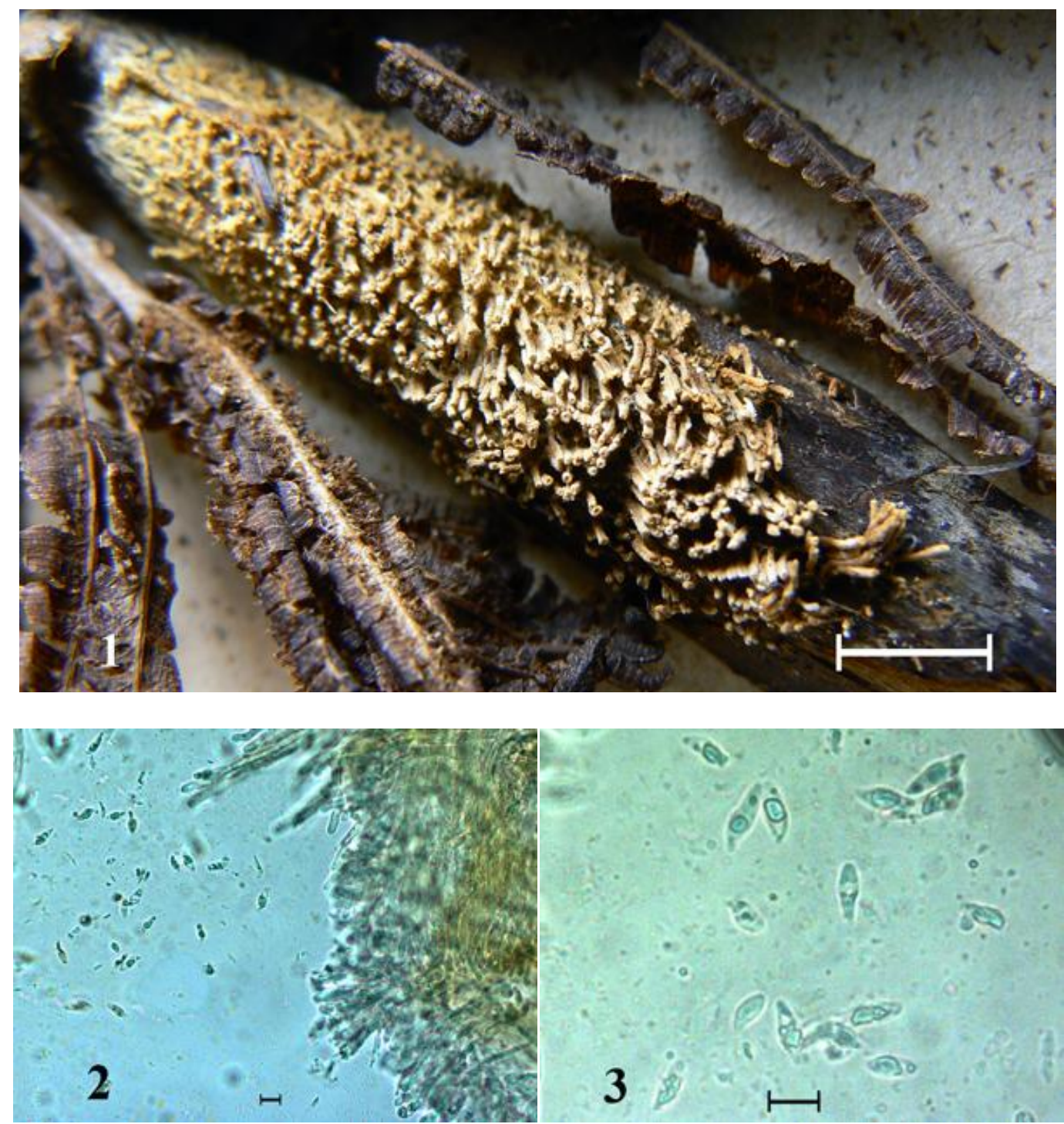

Figs 1-3 - Woldmaria filicina. 1 Basidiocarps (on $M$. struthiopteris, in herbarium). 2 Basidiospores, basidia. 3 Basidiospores. - Bars $=1=1 \mathrm{~cm}, 2,3=10 \mu \mathrm{m}$.

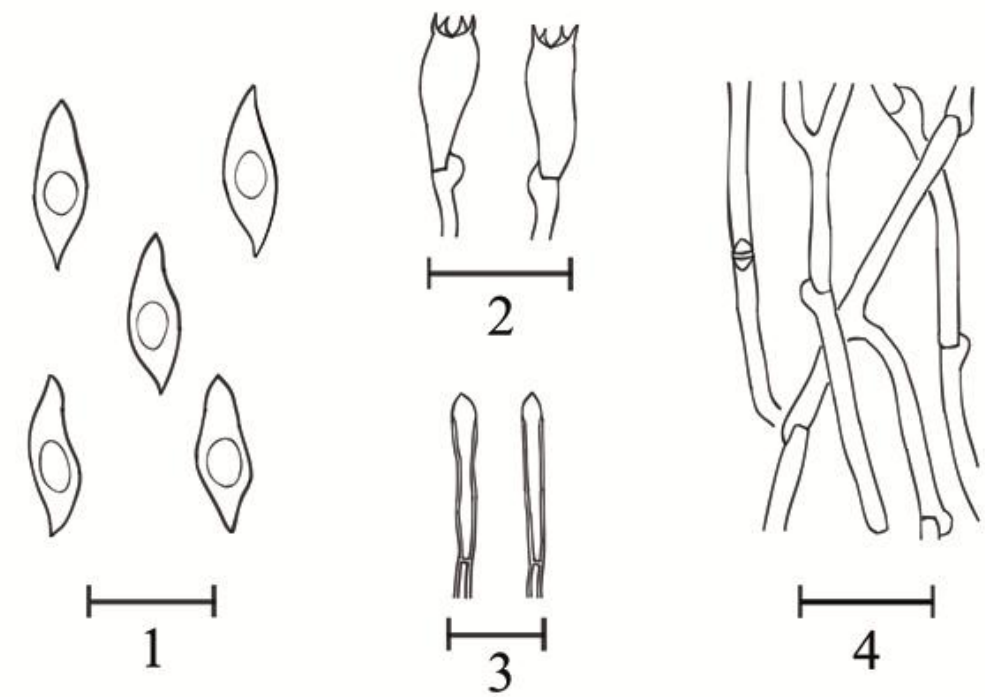

Fig 4 - Woldmaria filicina (microstructure). 1 Basidiospores. 2 Basidia. 3 Marginal hairs. 4 Hyphae. - Bars $=1=10 \mu \mathrm{m}, 2,3,4=30 \mu \mathrm{m}$. 


\section{Discussion}

This species is most common in Europe, especially in the Nordic Countries, in which mushrooms are well studied for example in Finland, in which 983 species of aphyllophoroid fungi are known (Hansen \& Knudsen 1997, Kotiranta et al. 2009, Kunttu et al. 2011).

In Northern Europe the species recorded in Denmark, Norway, Sweden (Woldmar 1954, Ryman \& Holmàsen 1984, Forstinger et al. 1990 (reference to the herbarium IB), Hansen \& Knudsen 1997, Vesterholt et al. 2003, Bodensteiner et al. 2004, Knudsen \& Vesterholt 2008, Discoverlife 2013), in Estonia (Saar et al. 2007). In Western Europe the species recorded in Austria (Poelt \& Jahn 1963, Forstinger et al. 1990, Koller 2012), in the United Kingdom, in Scotland (Discoverlife, 2013). In Central Europe the species recorded in Poland (Piatek \& Bujakiewicz 2004), in Czech Republic (Pilát 1926, Kotlaba \& Pouzar 1975). In Eastern Europe the species was found in Romania (Toma 1973, Bontea 1985) and in the Ukraine (Akulov et al. 2003). Data on the distribution of this species in southern Europe are absent, no data for France, the Netherlands, Switzerland and Germany and some other countries. Some published data on distribution of the cyphellaceous fungi in Europe were not available to us, links to them can be found in the publication B. Oertel (Oertel 2011).

Besides Europe this species was recorded in the USA and Canada (Cooke 1961, Bujakiewicz 1987, Ginns \& Lefebvre 1993, Dalpé 2009).

Distribution of W. filicina in Russia is presented on Fig. 5. This species was found in the European part of Russia in three regions: Pskovsk Region, Leningrad Region, Vologodsk Region (Red Book ... 2004). This fungus in the Vologda Region is included in the Red Book with the status of rare species. On the Urals (in Sverdlovsk Region), this fungus was found in the mixed forests of the middle taiga (Shiryaev et al. 2009).

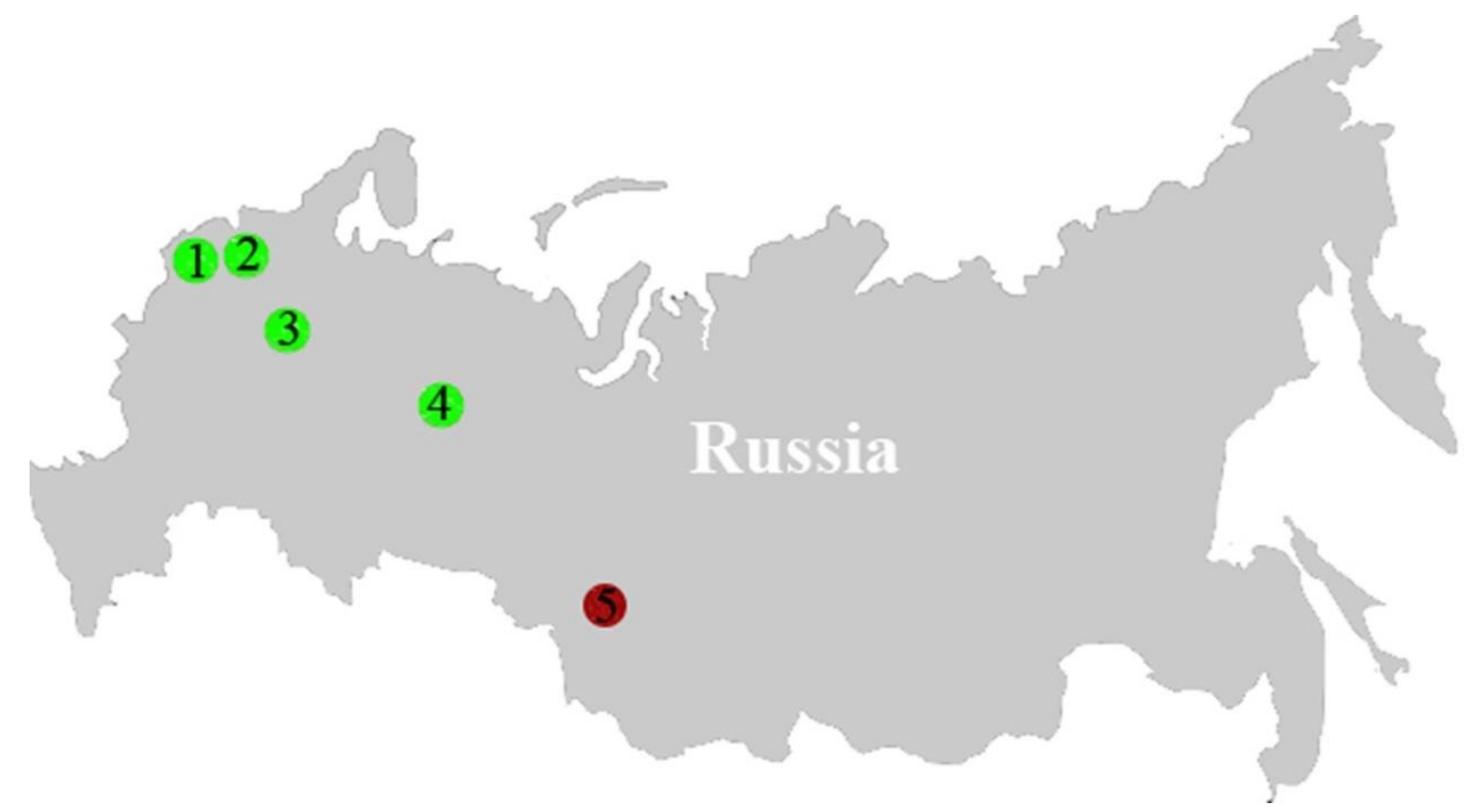

Fig. 5 - Distribution W. filicina in Russia. 1 Pskovsk Region. 2 Leningrad Region. 3 Vologodsk Region. 4 Sverdlovsk Region. 5 Novosibirsk Region (new location).

W. filicina different from other fungi specifics of a substratum, the fungus grows only on fern of M. struthiopteris. In the study area, in the forest-steppe zone of Western Siberia, W. filicina grows in moist shaded habitats, near streams, drainage pits and pits formed in the forest.

Typical habitat of W. filicina shown on Fig. 6. - Ravines of Plateau Watershed, which are formed in the vicinity of the small rivers, which brings together streams of rainwater and meltwater. Plant communities with domination of M. struthiopteris grow in the bottom of the ravine. 
The fern of M. struthiopteris is unusual and specific substrate for mushrooms. On this fern can be expected findings of other cyphellaceous fungi. We found nival Myxomycetes (Slime Molds) of Lamproderma arcyrioides (Sommerf.) Rostaf. (Fig. 6) on M. struthiopteris for the first time in Western Siberia and in the forest-steppe zone, it also testifies to specificity that of a substratum. In the spring, in April and May in the woods in the pits overgrown with bushes and ferns on the border of snowmelt live nival Myxomycetes, forming sporocarps on old stems of ferns, towering above the snow, where the air is warm and dry, these conditions are optimal for their education.

On the literature data W. filicina can grow in plantings fern (Piatek \& Bujakiewicz 2004), but this feature is not seen by us in Siberia, what can be related to the ecology of the species and its confinement to the wet habitats. This is due to the fact that in plantings fern (for example, in plantings of the botanical garden) the climate is less humid. In addition, in plantings of the botanical garden old stems at ferns removed, on it the fungus cannot appear.

The information obtained may be indicative of uniqueness diversity of fungi of the intrazonal plant communities in forest-steppe zone.

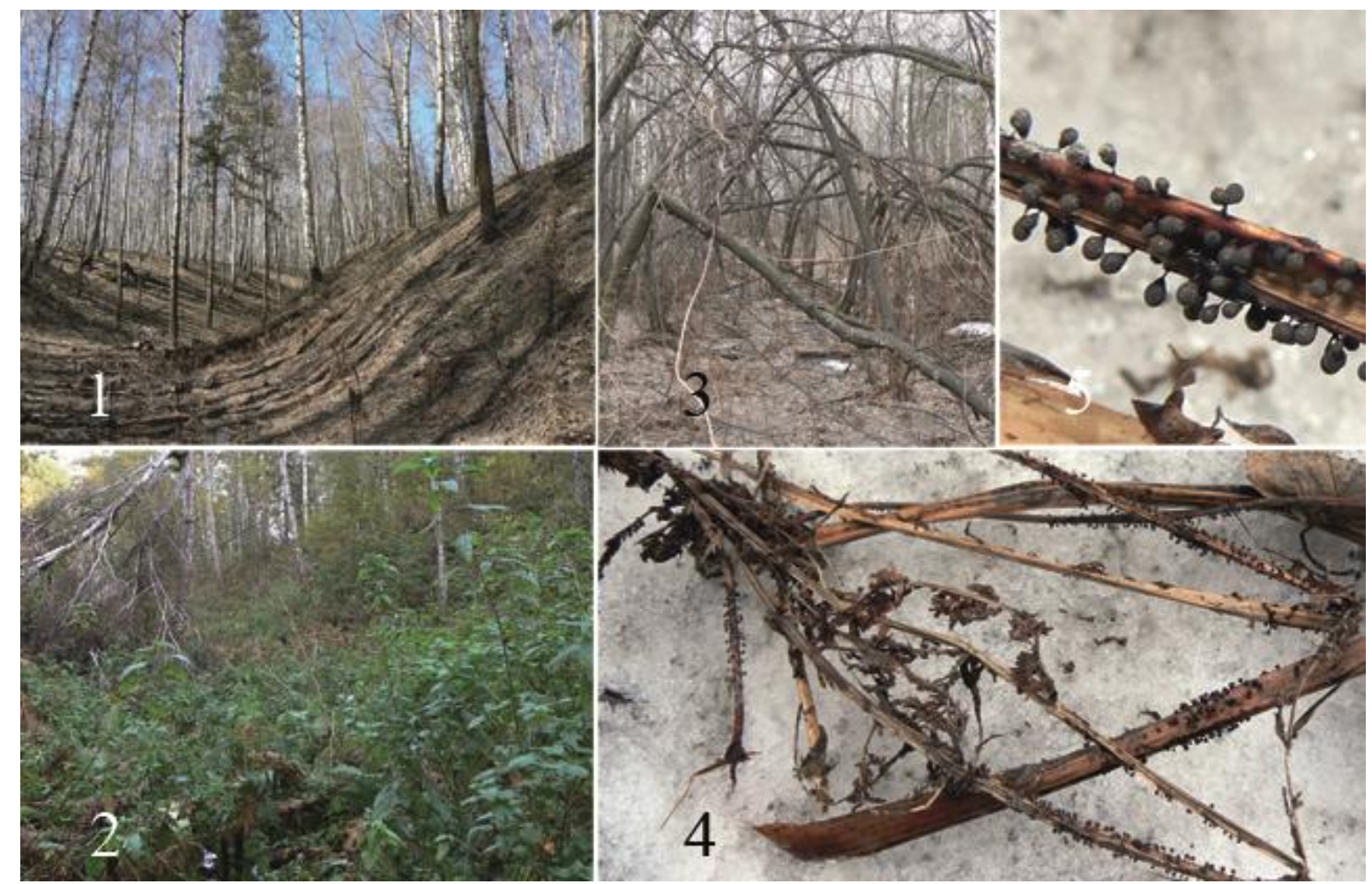

Fig. 6 - Habitats and substratum. 1, 2, 3 Habitats of $W$. filicina in forest-steppe zone of Western Siberia. - Nival myxomycetes. 4, 5 Lamproderma arcyrioides on $M$. struthiopteris on the border of the melting snow.

\section{Acknowledgements}

This work is performed within a grant RFBR 12-04-31262 Mol_a. We thank Dr. Nikolay B. Ermakov (CSBG SB RAS) for classification of types of plant communities.

\section{References}

Akulov OYu, Usichenko AS, Leontyev DV, Yurchenko EO, Prydiuk MP. 2003 - Annotated checklist of aphyllophoroid fungi of Ukraine. Mycena 2 (2), 1-73.

Bodensteiner P, Binder M, Monclavo J-M, Agerer R, Hibbett DS. 2004 - Phylogenetic relationships of cyphelloid homobasidiomycetes. Molecular Phylogenetics and Evolution 33, 501-515. 
Bondartseva MA, Parmasto EH. 1986 - Determinant of fungi of the USSR. The order Aphyllophorales. 1. Nauka, Leningrad 1-192 [in Russian].

Bontea V. 1985 - Ciuperici parazite şi saprofite din România. 1. Editura Academiei Republicii Socialiste România, Bucureşti 1-586.

Bujakiewicz A. 1987 - Macromycetes occurring in floodplain forests near Ithaca, New York, USA. Acta Mycologica 21, 165-192.

Cooke WB. 1961 - The cyphellaceous fungi. A study in Porotheleaceae. Sydowia Beihefte 4, 1144.

Dalpé Y. 2009 - Liste des macromycètes récoltés et rarement observés en Outaouais - 247 espèces. Période 1984-2009. http://www.mao-qc.ca/myco/images/MAOespecesrares1984-2009.pdf

Dämon W. 2001 - Notizen zur Pilzflora des Bundeslandes Salzburg. 1. Linzer biologische Beiträge 33 (2), 723-796.

Forstinger H, Hausknecht A, Rücker TH. 1990 - Bemerkenswerte Pilzfunde aus Salzburg. IV. Mitteilungen der Gesellschaft für Salzburger Landeskunde 130, 739-751.

Gilbertson RL, Ryvarden L. 1986 - North American Polypores. Vol. 1: Abortiporus-Lindtneria. Oslo, Fungiflora 1-433.

Ginns J, Lefebvre MNL. 1993 - Lignicolous corticioid fungi of North America. Systematics, distribution, and ecology. Mycologia Memoirs 19, 1-247.

Hansen L, Knudsen H. 1996 - Nomenclatural notes to Nordic Macromycetes. Vol. 1, 3. Nordic Journal of Botany 16 (2), 211-221.

Hansen L, Knudsen H. 1997 - Nordic Macromycetes. Vol. 3: Heterobasidioid, aphyllophoroid and gasteromycetoid basidiomycetes. Copenhagen, Nordsvamp 1-444.

Knudsen H, Vesterholt J (eds). 2008 - Funga Nordica. Agaricoid, boletoid and cyphelloid genera Copenhagen, Nordsvamp 1-965.

Koller G. 2012 - Woldmaria filicina (Peck) Knudsen. http://mushroomobserver.org/96454

Kotiranta H, Saarenoksa R, Kytövuori. 2009 - Aphyllophoroid fungi of Finland. A check-list with ecology, distribution and thread categories. Norrlinia 19, Helsinki university print 1-223.

Kotkova VM. 2006 - Mycobiota of the Altai Republic. News systematics of lower plants 39, 129133 [in Russian].

Kotlaba F, Pouzar Z. 1975 - Contribution to the knowledge of the macromycetes of the Diana Virgin Forest near Tachov (Western Bohemia). Zpr. Muz. Západočes. Kr., Plzeň, Přiroda 17, 5-13.

Kunttu P, Kulju M, Pennanen J, Kotiranta H, Halme P. 2011 - Additions to the Finnish aphyllophoroid fungi. Folia Cryptogamica Estonica 48, 25-30.

Mukhin VA, Knudsen H. 1998 - The Evolution of high latitudinal altitudinal biotas of xylotrophic basidiomycetes. Arctic and Alpine mycology 5: Proceedings of the Fifth International Symposium on the Arcto-Alpine Mycology. Abstract. Yekaterinburg, Yekaterinburg publisher 141-151.

Oertel B. 2011 - Pilzgattungen Europas. Liste 2: Notizbuchartige Auswahlliste zur Bestimmungsliteratur für cyphelloide Pilze. http://www.dgfm-ev.de/sites/default/files/LitCyphelloide-Pilze.pdf

Piatek M, Bujakiewicz A. 2004 - Lachnella villosa and Woldmaria filicina, two remarkable cyphellaceous fungi from Poland. Polish Botanical Journal 49 (2), 145-150.

Pilát A. 1926 - Zwei neue Arten aus der Gattung Cyphella Fr. aus der Tschechoslowakei. Hedwigia 66, 261-264.

Poelt J, Jahn H. 1963 - Mitteleuropäische Pilze. E. Cramer, Hamburg 1-72.

Red Book of the Vologda Region. 2004 - Vol. 2. Plants and mushrooms. Vologda, VSPU, publisher Russ, 1-360 [in Russian].

Ryman S, Holmâsen I. 1984 - Svampar. En fälthandbok. Interpublishing, Stockholm 1-718.

Saar I, Lõhmus A, Parmasto E. 2007 - Mycobiota of the Poruni old-growth forest (Estonia, Puhatu Nature Reserve). Forestry Studies 47, 71-86. 
Shiryaev AG, Kotiranta H, Mukhin VA, Stavishenko IV, Ushakova NV. 2009 - Aphyllophoroid fungi of Sverdlovsk Region, Russia: biodiversiti, distribution, ecology and the IUCN threat categories. Ekaterinburg, Goshchitskiy Publisher 1-304.

Toma M. 1973 - Doua Cyphallaceae noi in micoflora Romaniei. St. Si. Cere. Biol., Seria Botanica 25 (4), 301-302.

Vesterholt J, Koch J, Eilenberg J, Frisvad J, Søchting U, Rosendahl S. 2003 - The List of Danish fungi - preliminary. http://www.danbif.dk/serv/fol915322/fungi1.pdf/download

Woldmar S. 1954 - Solenia crocea Karst. - en förbisedd svampart. Friesia 5 (1), 96-98.

Woldmar S. 1956 - Några västsvenska svampfynd. Friesia 5 (3-5), 425-432.

Woldmar S. 1959 - Ett danskt fynd av Solenia crocea. Friesia 6 (1), 49.

www.discoverlife.org - 2013.

www.mycobank.org - 2013.

Zhukov AM. 1980 - Wood-decay fungi of Priobie. Algae, fungi and lichens of southern Siberia. Moscow, Nauka 144-183 [in Russian]. 